\title{
THE EFFECT OF PARAGENETIC FACTORS ON PERFORMANCE TRAITS IN COMPLETE LACTATIONS IN SIMMENTAL COWS ${ }^{1}$
}

\author{
M. D. Petrović, Z. Skalicki, V. Bogdanović, M. M. Petrović, V. Kurcubić2
}

Abstract: The effect of paragenetic factors on performance traits in complete lactations was investigated on a sample of 143 Simmental cows housed at the "Zlatiborski Suvati" (Zlatibor Pastures) farm.

The examination was, namely, made on the effects of the lactation number, calving season and the age at first fertilization on the expression of the performance traits such as lactation duration, milk and milk-fat production, milk-fat content and $4 \% \mathrm{FCM}$ production in complete lactations.

The mean $(\mu)$ for the complete lactation duration was 335.73 days, that for milk production was 4564 $\mathrm{kg}$, the mean for milk-fat production was $166.7 \mathrm{~kg}$ and the means for the milk-fat content and $4 \% \mathrm{FCM}$ production were $3.66 \%$ and $4330 \mathrm{~kg}$, respectively.

The effect of the lactations on all the performance traits was very highly significant $(p<0.001)$, excepting the duration of complete lactations where the effect was statistically insignificant $(p>0.05)$. The calving season exerted a statistically significant and very highly significant effects on all the traits, except on the milk production in complete lactations $(\mathrm{p}>0.05)$. The age at first fertilization had a statistically significant $(p<0.05)$ impact on the production of milk, milk fat and $4 \%$ FCM, but it did not significantly affect the complete lactation duration and milk-fat content $(\mathrm{p}>0.05)$.

Key words: Simmental breed, complete lactation, milk production, calving season.

\section{Introduction}

In order to accurately assess the breeding value of certain individuals in a population, it is necessary to examine the paragenetic factors affecting variability of phenotypic values. Some of the factors are number of lactation, calving season, or the beginning of lactation and age at first fertilization.

Practice and findings of almost all researchers (Lazarević et al., 1985, 1987; Nenadović et al., 1987; Milojić Miroslava et al., 1988; Miščević et al., 1995; Urban et al., 1998) show that maximum milk production depends on the rearing intensity in the period from third to fifth lactations. The lowest milk production is achieved in the first lactation due to an insufficient body development of the cow. In his investigations of the effect of genetic and some paragenetic factors on milk yield in three Simmental genotypes (German and Slovenian Simmental and domestic spotted cattle), Perišić (1998) noted that lactation sequence very significantly $(\mathrm{p}<0.01)$ affected milk production and milk-fat content and production in all the three genotypes.

The effect of the calving season or the onset of lactation on the performance traits can be presented through different climatic factors and nutrition throughout the year. According to Chauhan and Hill (1986) the most favourable season, when milk yield is significantly increased, is August-January, the least favourable being in February-July, particularly after May when a drastic decrease is registered. Miščević (1995) established by the LSM method that the calving season significantly affected $(p<0.05)$ milk and milk-fat production and milk-fat content in complete lactations. In their studies of the active Simmental population in Serbia, Petrovic et al. (1997) record a significant deviation in milk performance traits from the general mean (excluding the milk-fat content) depending on the calving season $(\mathrm{p}<0.05)$. Perišić (1998) determined that the calving season very significantly $(\mathrm{p}<0.01)$ affected the milk traits except the milk-fat content on which it did not have a statistically significant effect $(\mathrm{p}>0.05)$.

Literature data in terms of the effect of age at first fertilization or calving on fertility and milk performance traits are rather differing and contradictory. Fiss and Wilton (1989) underline that with an age increase at first calving milk yield is increased. An analysis of optimal age at first calving in different breeds, made by Michel et al. (1989) showed that with each month of older age at first fertilization or calving milk

1 Original scientific paper - supported by the Ministry of Science and Technology, Project no. TR6858 - Originalni naučni rad je finansiran od strane Ministarstva za nauku i tehnologiju Projektom broj: TR6858

2 Mr Milun D. Petrović, asisstent professor, Dr Vladimir Kurćubić, asisstent professor, Faculty of Agronomy, Čačak; Dr Zlatko Skalicki, full-time professor, Dr Vladan Boganović, docent, Institute of Animal Science, Faculty of Agriculture, Zemun-Belgrade; Dr Milan M. Petrović, scientific counselor, Institute for Animal Husbandry, Zemun-Belgrade; Serbia and Montenegro. 
production is increased by $44 \mathrm{~kg}$. Tomsik (1990) determined a very weak and significant correlation $\left(r_{x y}=0.13\right)$ between the age at first calving and milk production per lactation. The effect of age at first fertilization on the milk performance traits in the first calvers in complete lactations (Perišić, 2002) was statistictically insignificant in regard to lactation duration and milk-fat content $(\mathrm{p}>0.05)$, and statistically very significant $(\mathrm{p}<0.01)$ as regards milk and milk-fat yields.

\section{Material and Methods}

The effects of paragenetic factors on the performance traits in complete lactations were investigated in 143 Simmental cows housed at the "Zlatiborski Suvati" (Zlatibor Pastures) farm having a loose housing system and lying boxes.

Investigations were made on the effects of lactation group, calving season and age at first fertilization on the expression of the performance traits of complete lactations such as duration of lactation (DCL), milk production (MPCL), milk-fat content (MFCCL), milk-fat production (MFPCL) and 4\% FCM production (4\%FCMCL).

Mathematical-statistical data analysis, that is all the required values (least square means and variance components) were calculated using the general linear model:

$$
\mathrm{y}_{\mathrm{ij}}=\mu+\mathrm{L}_{\mathrm{i}}+\mathrm{S}_{\mathrm{j}}+\mathrm{b}_{1}\left(\mathrm{x}_{1}-\bar{x}_{1}\right)+\mathrm{e}_{\mathrm{ij}}, \text { where }
$$

$\mathrm{y}_{\mathrm{ij}}-$ is an individual of $\mathrm{i}^{\text {th }}$ lactation and $\mathrm{j}^{\text {th }}$ season,

$\mu$ - is the general population mean at equal occurrence of all effect groups (L, S)

$\mathrm{L}_{\mathrm{i}}$ - is a fixed effect of $\mathrm{i}^{\text {th }}$ lactation group (1-7),

$\mathrm{S}_{\mathrm{j}}$ - is a fixed effect of $\mathrm{j}^{\text {th }}$ season (1-4),

$b_{1}-$ is a linear regression coefficient of the effect of age at first fertilization and

$\mathrm{e}_{\mathrm{ij}}$ - other undetermined effects.

Further analysis of the performance traits of the standard lactations presents variance components according to the given model, significance of factors, sum of squares, $\%$ of the sum of the total and the coefficients of determination for each trait examined.

\section{Results and Discussion}

The effect of lactation group and calving season on the performance traits in complete lactations is presented in table 1 .

Table 1. Least square means for the cow milk performance traits in complete lactations

\begin{tabular}{|c|c|c|c|c|c|c|c|c|c|c|}
\hline Traits & \multirow{2}{*}{\multicolumn{2}{|c|}{$\frac{\text { DCL (days) }}{335.73}$}} & \multicolumn{2}{|c|}{ MPCL (kg) } & \multirow{2}{*}{\multicolumn{2}{|c|}{$\frac{\text { MFCCL }(\%)}{3.66}$}} & \multicolumn{2}{|c|}{ MFPCL (kg) } & \multirow{2}{*}{\multicolumn{2}{|c|}{$\frac{4 \% \mathrm{FCMCL}(\mathrm{kg})}{4330.45}$}} \\
\hline \multirow{2}{*}{$\frac{\text { Mean }(\mu)}{\text { Lactation group }}$} & & & \multicolumn{2}{|c|}{4564.17} & & & \multicolumn{2}{|c|}{166.69} & & \\
\hline & \multicolumn{2}{|r|}{$\mathrm{SE}_{\mathrm{S}}$} & LSM & $\mathrm{SE}_{\mathrm{LSM}}$ & LSM & $\mathrm{SE}_{\mathrm{LSM}}$ & LSM & $\mathrm{SE}_{\mathrm{LSM}}$ & $\overline{\text { LSM }}$ & $\mathrm{SE}_{\mathrm{LSM}}$ \\
\hline I (1) & 339.9 & 5.93 & 3342.1 & 106.67 & 3.83 & 0.02 & 128.18 & 3.95 & 3265.4 & 101.23 \\
\hline II (2) & 326.0 & 5.87 & 4192.0 & 105.54 & 3.73 & 0.02 & 156.33 & 3.91 & 4025.4 & 100.16 \\
\hline III (3) & 326.7 & 5.91 & 4697.7 & 106.23 & 3.70 & 0.02 & 173.82 & 3.93 & 4489.5 & 100.81 \\
\hline IV (4) & 345.4 & 6.22 & 5023.6 & 111.77 & 3.67 & 0.02 & 184.64 & 4.14 & 4779.1 & 106.07 \\
\hline V (5) & 343.5 & 6.95 & 5192.5 & 124.91 & 3.60 & 0.02 & 186.54 & 4.63 & 4874.2 & 118.55 \\
\hline VI $(6+7)$ & 344.7 & 8.75 & 5151.3 & 121.44 & 3.54 & 0.02 & 182.24 & 4.50 & 4783.3 & 115.25 \\
\hline VII $(8+9+10)$ & 323.9 & 11.30 & 4350.0 & 203.13 & 3.56 & 0.03 & 155.08 & 7.52 & 4096.3 & 192.78 \\
\hline $\mathrm{F}_{\text {exp }}$ & \multicolumn{2}{|c|}{$1.93^{\mathrm{NS}}$} & \multicolumn{2}{|c|}{$34.19^{*}$} & \multicolumn{2}{|c|}{$31.80^{*}$} & \multicolumn{2}{|c|}{$25.26^{*}$} & \multicolumn{2}{|c|}{$28.76^{*}$} \\
\hline \multicolumn{11}{|l|}{ Calv. Season } \\
\hline I & 344.9 & 4.84 & 4907.0 & 87.07 & 3.65 & 0.01 & 178.48 & 3.22 & 4644.3 & 82.63 \\
\hline II & 331.2 & 4.80 & 4294.2 & 86.27 & 3.66 & 0.01 & 156.36 & 3.19 & 4070.1 & 81.87 \\
\hline III & 339.1 & 6.29 & 4520.6 & 113.12 & 3.67 & 0.02 & 165.73 & 4.19 & 4299.4 & 107.36 \\
\hline IV & 327.7 & 4.81 & 4534.9 & 86.43 & 3.67 & 0.01 & 166.19 & 3.20 & 4308.0 & 82.02 \\
\hline$\overline{\mathrm{F}_{\mathrm{exp}}}$ & \multicolumn{2}{|c|}{2.72} & \multicolumn{2}{|c|}{$9.33^{*}$} & \multicolumn{2}{|c|}{$0.59^{\mathrm{NS}}$} & \multicolumn{2}{|c|}{8.76} & \multicolumn{2}{|c|}{$9.04^{* *}$} \\
\hline
\end{tabular}


As it is seen from the table, the seven lactation groups very highly significantly affected $(p<0.001)$ milk performance traits in complete lactations, with the exception of the duration of complete lactations where the effect of lactation was not statistically significant $(\mathrm{p}<0.05)$. The highest milk, milk-fat and $4 \%$-fatcorrected milk productions were recorded in the fifth lactation, with the deviations of milk, milk-fat and $4 \%$ FCM productions from the mean being $628.3 \mathrm{~kg}, 19.85 \mathrm{~kg}$ and $543.7 \mathrm{~kg}$, respectively. Minimal milk performance was achieved in the first lactation, where milk, milk-fat and 4\% FCM productions were by $1222.1 \mathrm{~kg}, 38.5 \mathrm{~kg}$ and $1065 \mathrm{~kg}$, respectively, lower than the mean. An adverse trend was registered in the milk-fat content compared to the milk and milk-fat yields and therefore the highest milk-fat content was produced in the first or minimal lactation, where it was $0.17 \%$ higher than the mean and the lowest one in the sixth lactation group with the $0.12 \%$ lower content compared to the mean. Similar research results are recorded by Lazarević et al. (1985, 1987) Nenadović et al. (1987) Milojić Miroslava et al., 1988, Miščević et al. (1995) Urban et al. (1998).

The calving season, through diet and temperature, statistically very highly significantly $(p<0.001)$ affected the production of milk, milk-fat and $4 \%$ fat-corrected milk, whereas it had a significant effect on the lactation duration $(\mathrm{p}<0.05)$. The effect of the season on the milk-fat content was not statitistically significant $(\mathrm{p}>0.05)$.

The longest lactation duration was recorded in the spring (344.9 days) season and the shortest one (327.7 days) in the winter period.

Milk, milk-fat and $4 \%$ fat-corrected milk productions in complete lactations were highest in the spring season when $342.83 \mathrm{~kg}$ more milk, $11.79 \mathrm{~kg}$ more milk-fat and $313.85 \mathrm{~kg}$ more $4 \%$ FCM were produced compared to the mean. The lowest production was recorded in the summer season, when milk, milkfat and 4\% FCM productions were by $269.93 \mathrm{~kg}, 10.33 \mathrm{~kg}$ and $260.35 \mathrm{~kg}$, respectively, lower than the mean. The lowest production in the summer season was due to an unfavourable effect of high temperature on the cows' performance because of a lower food intake by cows during high temperature periods. The highest production in the spring and partly in the winter seasons was achieved due to a favourable effect of green feed on milk performance and its lower decrease after the maximum reached at the beginning of lactation.

The milk-fat content was highest in the autumn and winter seasons (3.66\%) and lowest in the spring season. Though insignificant, the differences that occurred were due to the effect of dried roughage and silage in the winter period and green feed that caused a certain decrease in the milk-fat content in the spring and summer seasons.

The literature results on the season effect on performance traits are quite contradictory. Saveli (1997) for instance, emphasized that the calving season effect in a high-yielding herd was not statistically significant, as opposed to the herd with a lower production level where in the cows calved in the winter period milk and milk-fat productions were statistically significantly higher $(+654 \mathrm{~kg}$ milk and $+25 \mathrm{~kg}$ milk-fat) than the production in the cows that had calved in the summer period. Based upon this, the author stressed the importance of favouring the winter calving to the summer one in the herds with a lower diet level, which would result in an increase in milk production particularly in the period of a higher milk price. The calving season effect, according to the author, should be regarded as a model for the estimation of the breeding value of milking cows. Similar results, being maximum winter season, were presented by Petrović et al. (1997) and Perišić (1998) in their studies. Conversely, Miščević (1995) and Chauhan and Hill (1986) singled out the summer calving season as the maximal one.

The effect of age at first fertilization on the performance traits in complete lactations was presented through linear regression coefficients and equation calculated according to the general linear model.

The linear regression coefficients and regression equations are presented in table 2.

Table 2. Regression analysis of the effect of age at first fertilization on milk performance traits in complete lactations using the general linear model

\begin{tabular}{cccccc}
\hline \multicolumn{5}{c}{ Linear regression coefficients for milk performance traits in complete lactations } \\
\hline Traits & DCL $($ days $)$ & MPCL $(\mathrm{kg})$ & MFCCL $(\%)$ & MFPCL $(\mathrm{kg})$ & $4 \%$ FCMCL $(\mathrm{kg})$ \\
\hline $\mathrm{a}$ & $283.07^{* * *}$ & $3451.58^{* * *}$ & $3.58^{* * *}$ & $122.56^{* * * *}$ & $3230.06^{* * * *}$ \\
\hline Age at I fertilizat.- $\mathrm{b}_{\mathrm{xy}}$ & $0.057^{\mathrm{NS}}$ & $1.508^{*}$ & $-0.000^{\mathrm{NS}}$ & $0.056^{*}$ & $1.464^{*}$ \\
\hline Regr.equations & $\mathrm{y}=283.1+0.06 \mathrm{x}$ & $\mathrm{y}=3451.6+1.51 \mathrm{x}$ & $\mathrm{y}=3.58-0.000 \mathrm{x}$ & $\mathrm{y}=122.6+0.06 \mathrm{x}$ & $\mathrm{y}=3230.1+1.46 \mathrm{x}$ \\
\hline N.S. - P $>0.05 ; *-\mathrm{P}<0.05 ;$ & $* *-\mathrm{P}<0.01 ;$ & $* * *-\mathrm{P}<0.001 ;$ & & &
\end{tabular}


Based upon the data presented in the table it could be concluded that the age at first fertilization did not affect the duration of complete lactations and milk-fat content in them, considering that the linear regression coefficients obtained were not statistically significant $(\mathrm{p}>0.05)$. The age at first fertilization statistically significantly $(\mathrm{p}<0.05)$ affected the productions of milk, milk-fat and $4 \%$ fat-corrected milk. Based upon the regression coefficients obtained for the traits, milk production, milk fat and $4 \% \mathrm{FCM}$ were increased by $1.508 \mathrm{~kg}, 0.056 \mathrm{~kg}$ and $1.464 \mathrm{~kg}$ with each day of the age increase at first fertilization.

Perišić (1998) mentioned that the age at first fertilization statistically very significantly $(\mathrm{p}<0.01)$ impacted milk and milk-fat productions in complete lactations, but had not a significant effect on the duration of lactations and the milk-fat content, as in our investigations ( $>0.05)$.

The variance components for the performance traits in complete lactations, or the significance of the factors examined, sums of squares and the percentage of the square sums of the sum of the total are presented in table 3. The table also presents the coefficients of determination $\left(\mathrm{R}^{2}\right)$, being a remainder of the residual variance divided by 100 .

Table 3. Variance components for milk performance traits in complete lactations. Significance of factors, sums of squares and \% of the sum of the total

\begin{tabular}{|c|c|c|c|c|c|c|}
\hline $\begin{array}{c}\text { Source } \\
\text { Traits }\end{array}$ & Lactation gr. & Season & Age at I fert. & Model & Residual var. & $\mathrm{R}^{2}$ \\
\hline Degrees of freed. & 6 & 3 & 1 & 10 & 788 & - \\
\hline DCL (days) & $\begin{array}{c}\mathrm{ns} \\
56134.35 \\
1.43\end{array}$ & $\begin{array}{c}39451.89 \\
1.01\end{array}$ & $\begin{array}{c}\mathrm{ns} \\
9676.96 \\
0.25\end{array}$ & $\begin{array}{c}105263.20 \\
2.69\end{array}$ & $\begin{array}{c}3811058.24 \\
97.31\end{array}$ & 0.027 \\
\hline MPCL (kg) & $\begin{array}{c}320706437.5 \\
20.00\end{array}$ & $\begin{array}{c}* * * \\
43780872.8 \\
2.73\end{array}$ & $\begin{array}{c}6793419.9 \\
0.42\end{array}$ & $\begin{array}{c}371280730.2 \\
23.16\end{array}$ & $\begin{array}{c}1231932513.7 \\
76.84\end{array}$ & 0.232 \\
\hline MFCCL (\%) & $\begin{array}{c}* * * \\
6.95 \\
19.47\end{array}$ & $\begin{array}{c}\text { ns } \\
0.06 \\
0.17\end{array}$ & $\begin{array}{c}\text { ns } \\
0.00 \\
0.00\end{array}$ & $\begin{array}{c}* * * \\
7.01 \\
19.64\end{array}$ & $\begin{array}{l}28.69 \\
80.36\end{array}$ & 0.196 \\
\hline MFPCL $(\mathrm{kg})$ & $\begin{array}{c}* * * \\
325154.60 \\
15.62\end{array}$ & $\begin{array}{c}56362.37 \\
2.85\end{array}$ & $\begin{array}{c}9214.93 \\
0.44\end{array}$ & $\begin{array}{c}390731.89 \\
18.77\end{array}$ & $\begin{array}{c}1690417.17 \\
81.23\end{array}$ & 0.188 \\
\hline 4\%FCMCL $(\mathrm{kg})$ & $\begin{array}{c}242969615.1 \\
17.39\end{array}$ & $\begin{array}{c}38198294.6 \\
2.73\end{array}$ & $\begin{array}{c}* \\
6402269.2 \\
0.46\end{array}$ & $\begin{array}{c}287570178.9 \\
20.58\end{array}$ & $\begin{array}{c}1109536832.5 \\
79.42\end{array}$ & 0.206 \\
\hline
\end{tabular}

The table shows that the model used was statistically very highly significant $(p<0.001)$ for all the traits, except for the duration of complete lactations where it was statistically significant $(p<0.05)$, which justified the use of the model selected.

The determination coefficients $\left(\mathrm{R}^{2}\right)$, referring to the level of explanation of the variation of the trait by using the model selected, were lowest in the duration of lactation being only 0.027 , which is understandable considering the fact that it was the calving season only that had affected this trait significantly. The highest determination coefficient $\left(\mathrm{R}^{2}\right)$ was recorded with the milk yield in complete lactations, being 0.232 or $23.2 \%$ of the total variability of the trait, due to the effect of the lactation sequence, calving season and age at first fertilization. Based upon this it may be inferred that variability of the performance traits in complete lactations is also affected by a great number of factors not examined here.

\section{Conclusion}

Based upon the applied model for the correction of the effect of the paragenetic factors on the performance traits in complete lactations, the following may be inferred:

- The effect of lactation group on all the performance traits was very highly significant $(p<0.001)$, with the exception of the duration of complete lactations where the effect was statistically insignificant $(\mathrm{p}>0.05)$. 
- The calving season statistically significantly affected only the milk production in complete lactations $(p>0.05)$, whereas its effect on the other traits was significant and very highly significant, excepting the duration of complete lactations where no significant effect was recorded $(\mathrm{p}>0.05)$.

- The age at first fertilization exerted a statistically significant $(\mathrm{p}<0.05)$ impact on the productions of milk, milk-fat and 4\% FCM, but no impact on the duration of complete lactations and the milk-fat content ( $>0.05)$.

\title{
UTICAJ PARAGENETSKIH FAKTORA NA PROIZVODNE OSOBINE U PUNIM LAKTACIJAMA KOD KRAVA SIMENTALSKE RASE
}

\author{
M.D. Petrović, Z. Skalicki, V. Bogdanović, M.M. Petrović, V. Kurćubić
}

Rezime

Uticaj paragenetskih faktora na proizvodne osobine u punim laktacijama ispitivan je na uzorku od 143 krave simentalske rase sa farme "Zlatiborski suvati".

$\mathrm{Na}$ ispoljenost proizvodnih osobina u punim laktacijama, kao što su trajanje laktacija, proizvodnja mleka i mlečne masti, sadržaj mlečne masti i proizvodnja 4\% MKM, ispitivan je uticaj broja laktacija, sezone telenja i uzrasta pri prvoj oplodnji.

Opšti prosek $(\mu)$ za trajanje punih laktacija iznosio je 335.73 dana, proizvodnju mleka $4564 \mathrm{~kg}$, proizvodnju mlečne masti $166.7 \mathrm{~kg}$, sadržaj mlečne masti 3.66\% i proizvodnju $4 \% \mathrm{MKM} 4330 \mathrm{~kg}$.

Uticaj laktacija na sve proizvodne osobine bio je vrlo visoko značajan $(p<0.001)$, izuzimajući trajanje celih laktacija gde je uticaj bio statistički nesignifikantan $(p>0.05)$. Sezona telenja statistički značajno nije uticala samo na proizvodnju mleka celih laktacija $(\mathrm{p}>0.05)$, dok je na ostale osobine njen uticaj bio značajan i vrlo visoko značajan. Uzrast pri prvoj oplodnji je statistički značajno $(p<0.05)$ uticao na proizvodnju mleka, mlečne masti i $4 \%$ MKM, dok na trajanje celih laktacija i sadržaj mlečne masti nije značajno uticao $(\mathrm{p}>0.05)$.

\section{Literature}

1. CHAUHAN, V.P.S., HILL, W.G.(1986): Seasonal grouping in a herd-year-season model of sire evaluation. Animal Production, 43, 63-71.

2. FISS, F.C., WILTON, J.W.(1989): Effects of breeding system, cow weight and milk yield on reproductive performance in beef cattle. Journal of Animal Science, Vol. 67, Num. 7, 1714-1721.

3. LAZAREVIĆ, R., ROMČEVIĆ, LJ., VASOVIĆ, S., NIKITOVIĆ, N., MIHAJLOV, B.(1985): Varjabilnost proizvodnih i reprodukcijskih osobina krava simentalske rase. Savremena poljoprivreda, 33(1-2), p. 5-16, Novi Sad.

4. LAZAREVIĆ, R., VASOVIĆ, S., PETROVIĆ, M.M.(1987): Comparative tests of life-span production of simmental and european black-white breed cows. $38^{\text {th }}$ Annual Meeting of the European Association for Animal Production. Lisabon, Portugal, September $27^{\text {th }}$-October $1^{\text {st }}$.

5. MICHEL, A., LEUENBERGER, H., KUNZI, N. (1989): Optimales erstkalbealter fur gealpte rinder unterschiedlicher zuchtrichtung. Simentaler Fleckvieh 6, 15-19.

6. MILOJIĆ MIROSLAVA (1988): Povećanje proizvodnje mleka dugovečnih krava. Poljoprivreda, br 344345, p. 64-67, Beograd.

7. MIŠČ́EVIĆ, B., LAZAREVIĆ, R., VIDOVIĆ, V., ALEKSIĆ, S., PETROVIĆ, M.M.(1995): Ocena genetskih varijansi i koeficijenata naslednosti važnijih osobina mlečnosti krava simentalske rase. Bootehnologija u stočarstvu, 11(3-6), p. 81-86, Beograd-Zemun.

8. NENADOVIĆ, M., KARADŽIĆ, V., ILIĆ, V., FRANCUSKI, A., MIKLOŠ, J.(1987): Varijabilnost efikasnosti proizvodnje mleka u različitih genotipova goveda. Savremena poljoprivreda, 35( 3-4), p. 113124, Novi Sad. 
9. PERIŠIĆ, P. (1998): Reproduktivne i proizvodne osobine različitih genotipova krava simentalske rase. Magistarska teza, Poljoprivredni fakultet, Beograd-Zemun.

10. PERIŠIĆ, P., SKALICKI, Z., PETROVIĆ, M.M.(2002): Uticaj uzrasta pri prvoj oplodnji na neke reproduktivne i proizvodne osobine krava simentalske rase u prve tri laktacije. Biotechnology in Animal Husbandry 18(1-2), p.1-68, Beograd-Zemun.

11. PETROVIĆ, M.M., LAZAREVIĆ, R., LAZAREVIĆ, LJ., ALEKSIĆ, S., MIŠČEVIĆ, B., PERKOVIĆ, S.(1997): Proizvodni efekti selekcije aktivne populacije simentalskih goveda u Srbiji. Bootehnologija u stočarstvu, 13(3-4), p. 57-64, Beograd-Zemun.

12. SAVELI, O. (1997): Effects of calving season on evaluation of the breeding value of dairy cattle. Book of Abstracts of the $48^{\text {th }}$ Annual Meeting of the European Association for Animal Production, Vienna, Austrija, 25-28 August.

13. TOMSIK, P.(1990): Dairy performance of Czeck Piecd cows in an upland region. Anim. Breed. Abstr. 50: 523(Abstr.).

14. URBAN, F., BOUŠKA, J., BARTON, L.(1998): Diversification of the breed structure in cattle populationof the Czech Republic. Biotehnologija u stočarstvu, 14(5-6), p. 43-50. Beograd-Zemun. 